\title{
Magical Realism and Children's Literature: Diana Wynne Jones's Black Maria and Salman Rushdie's Midnight's Children as a Test Case
}

\author{
Teya Rosenberg
}

$\mathrm{S}$ ome years ago I tried to explain to a class exactly what kind of fantasy E. Nesbit wrote. I wanted to call it magical realism, but when I consulted Egoff's classifications of fantasy in Worlds Within (1988), I found that she felt magical realism could not exist in children's literature and created a category for works such as those of Nesbir and Edward Eager-'stories of magic'-and yet further categones for the works of authors such as Alan Garner. Susan Cooper, Diana Wynne Jones, and so on. Thinking of magical realism as texis that mix a detailed realism, or mimesis, with magical occurrences presented and accepted as a natural part of the reality, I found that most studies of children's fantasy separate such stories from those of high fantasy, in which there is an otherworld that either occupies all the space in a text or is linked to a mimetic world, but they do so by creating a plethora of categories.

Two books that might be considered magical realism and that are well known, Nesbit's Five Children and It (1902) and Lucy M. Boston's The Children of Green Knowe (1954), are rarely placed in the same category and never considered magical realism. Five Children and ${ }^{t} t$ is classified as a story of magic by Egoff, a comic fantasy by Diana Waggoner (1978), a light domestic fantasy by Judith Saltman (1985), and a magic adventure fantasy by Ruth Nadelman Lynn (1995). The Children of Greene Knowe is classified as enchanted realism (Egoff), a nostalgic fantasy (Waggoner), fantasy of time travel (Saltman), and ghost fantasy (Nadelman).' These multiple categories do not encourage consideration of techniques and ideas common to the texts so categorized. and some of the classifications (comic, nostalgic) do not encourage examining the ramifications of the magical as anything other than amusing. Examining such texts as magical realism, however, avoids these drawbacks and encourages more rigorous study of this common form of children's fantasy.

To open the discussion of children' s literature as magical realism. I compare a text for adults that is generally agreed to be magical realism with a children's text. Salman Rushdie's Midnight's Children (1980) and Diana Wynne Jones's Black Maria (1991) contain similarities but also suggest that there is a difference in scope between magical realist texts for adults and those for children. In comparison to those for children, those for adults do tend to be longer, deal explicitly with political or historical events or movements, are more specific in developing their points, supply more explanation. and spend more time or space describing characters, events. or situations. Children's magical realism texts are more action oriented and more likely to work by inference and implication. As Jill Paton Walsh has commented abour children's literature in general:

\begin{abstract}
The children's book presents a technically most difficult, technically most interesting problemthat of making a fully serious adult statement, as a good novel of any kind does, and making it utterly simple and transparent. It seems to me to be a dereliction of some kind, almost a betrayal of the young reader, to get out of the difficulty by putting down the adult's burden of knowledge and experience, and speaking childishly; but the need for comprehensibility imposes an emotional obliqueness, an indirectness of approach, which like elision and partial statement in poetry is often itself a source of aesthetic power

(Walsh 1977, pp.192-93)
\end{abstract}

In magical realism, the texts for children tend to deal more in the personal than the public, suggesting the wider implications of their events but nor specifically enumerating or describing them. The methods and techniques of magical realism are, however, shared by both sorts of text, varying from author to author, text to text, rather than from audience to audience. As representative of magical realism in general and as examples of works oriented to different audiences, Midnight's Children and Black Maria have similarities of narrative structure. imagery, and character construction that indicate they share a mode of expression although the ideas expressed within that mode are not identical. ${ }^{2}$ Still, both express ideas with larger implications: Rushdie about the political, cultural, and social ramifications of India's history in the twentieth century, Jones about gender expectations and relations in the later twentieth century. With this comparison, I hope to stan a larger conversation that will ultimately break down boundaries as arbitrary as the many boundaries magical realism has historically sought to demolish. 
The complicated history of the term magical realism began in 1929 with German painter Franz Roh, was taken over in the 1940s and 50s by Latin American writers, and has been revived and rethought periodically since then. There are many articles that review the history of the term, and I will not repeat their work here. ${ }^{3}$ Two works that I have found most useful for understanding the defining characteristics of the form are Amaryll Chanady's Magical Realism and the Fantastic: Resolved versus Unresolved Antinomy (1985) and Wendy B. Faris's 'Scheherazade's Children: Magical Realism and Postmodern Fiction' in Magical Realism: Theony, History. Community (1995). These two works are useful complements to each other, for Chanady scrutinizes the structural elements of the form while Faris concentrates on elements of content. Starting with Chanady's discussion and moving to Faris's creates a view of the form from its skeleton out.

Chanady establishes three criteria for a text to be considered magical realism. The first is that the work be characterized first of all by two conflicting, but autonomously coherent, perspectives, one based on an "enlightened" and rational view of reality, and the other on the acceptance of the supernatural as part of everyday reality' (Chanady 1985, pp. 21-22). This coexistence of perspectives is what she tems antinomy, and she contrasts the resolved antinomy of magical realism with the unresolved antinomy of the fantastic. That is, in the fantastic the two perspectives exist but are in conflict. That conflict is important to Chanady's second criterion. that 'In magical realism, the supernatural is not presented as problematic' (p. 23) and that 'resolution of logical antinomy in the description of events and situations' is crucial (p.26). Finally, Chanady's third criterion focuses on the implied author and the importance of authorial reticence. or absence of obvious judgments about the veracity of the events and the authenticity of the world view expressed by characters in the text" (p. 30). The lack of authorial judgement is meant to carry the readers beyond their own possible doubts. Thus, according to Chanady, magical realist texts are marked not only by the mixture of the natural and the supernatural but also by the attitude within the text to that mixture and the response it encourages from its audience.
Faris's discussion of magical realism is not as structuralist as Chanady's, although ultimately they describe similar elements. Faris identifies five primary characteristics of magical realism and then nine secondary characteristics. Where Chanady groups the supernatural and the realistic together as one criterion. Faris splits them into two characteristics: "The text contains an "irreducible element" of magic, something we cannot explain according to the laws of the universe as we know them' (Faris 1995. p.167) and 'Descriptions detail a strong presence of the phenomenal world - this is the realism in magical realism. distinguishing it from much fantasy and allegory' (p.169). The additional primary characteristics similarly touch on but do not exactly replicate Chanady's criteria. She considers the readers' role in the third characteristic: 'The reader may hesitate (at one point or another) between two contradictory understandings of events-and hence experiences some unsettling doubts' (p. 171): and in the fourth: 'We experience the closeness or near-merging of two realms, two worlds' (p. 172), she comes close to Chanady's analysis of the iwo perspectives. though she presents it more in terms of content than structure. Finally, she addresses the purpose and/or effect of magical realist works: "These texts question received ideas about time, space, and identity' (p. 173).

After these five primary characteristics that are necessary for every magical realist text, she identifies nine secondary characteristics that may or may not occur. These characteristics describe techniques. images and other content, and historical/literary context that many magical realist texts share:

1. Metafictional dimensions are common...the magical power of fiction itself, the capacities of mind that make it possible, and the elements out of which it is made-signs, images. metaphors. narrators, narratees-may be foregrounded... 2. ... a particular kind of verbalmagic-aclosing of the gap between words and the world, or a demonstration of what we might call the linguistic nature of experience. This magic happens when a metaphor is made real...

3. The narrative appears to the late-twentiethcentury adult readers to which it is addressed as fresh, childlike, even primitive. Wonders are 
recounted largely without commem, in a matterof-fact way, accepted-presumably-as a child would accept them, without undue questioning or reflection; they thus achieve a kind of defamiliarization that appears to be natural or artless..

4. Repetition as a narrative principle, in conjunction with mirrors or their analogues used symbolically or structurally, creates a magic of shifting references...

5. Metamorphoses are a relatively common event (though not as common as one might think). They embody in the realm of organisms a collision of wo different worlds..

6. Many of these texts take a position that is antibureaucratic, and so they often use their magic against the established social order...

7. In magical realist narrative, ancient systems of belief and local lore often underlie the text..

8. ... a Jungian rather than a Frevdian perspecive is common in magical realist texis; that is, the magic may be attributed to a mysterious sense of collective relatedness rather than so individual memories or dreams or visions...

9. A carnivalesque spirit is common in this group of novels...

(pp. 175-84)

These characteristics help Faris discuss magical realism as a postmodern form, and thus many are common to texts that are not necessarily magical realism. As well, not all of them apply to every example of magical realism; however, they do provide useful elements to consider when examining magical realist texts.

A common perception of magical realism is that it is a Latin American form only, but most recent critics of magical realism have shifted the emphasis away from Latin America, treating the form as global. Chanady asserts that it arises from a variety of artistic, creative, and political factors rather than from location or culture (Chanady 1995, p. 141). Faris is less specific commenting that the category of magical realism can be profitably extended to characterize a significant category of contemporary narrative in the West ' (p.165). Other critics similarly see magical realism as a global form, particularly those interested in postcolonial literatures, who see magical realism as a reaction against colonial power and paradigms, represented both by political realities and by the cultural imperialism of European realism. As Stephen Slemon, in 'Magical Realism as Postcolonial Discourse' notes,

recently, the locus for critical sindies on magic realism has been broadened from Lain America and the Caribbean to include speculations on its place in the literatures of India. Nigeria, and English Canada, this last being perhaps the most sta-tling development for magical realism in recent years, since Canada, unlike these other regions, is not part of the Third World, a condition long thought necessany to the currency of the term in regard to literature...

(Slemon 1995, pp.407-8)

The application of the term to literatures other than Latin American, and the growing acceptance of the possibility of the form from countries other than third world makes its discussion as a form in Western children's literature feasible. Children's literature has a long history of combining the natural and the supernatural in the manner Chanady and Faris describe. Furthermore, Faris's fourth secondary characteristic, that repetition is important to magical realism, and the seventh characteristic, that ancient systems of belief and lore often underlie the text, have both been identified in children's literature (See Gannon 1987. Sullivan 1990. Nikolajeva 1994). Few, however. have connected children's literature with the political elements obvious in magical realism for adults. The bulk of critical attention about magical realism has focused on the political purpose of the form. its production from marginalized cultures and its desire to look at, in Garcia Márquez's words, 'reality ... without the limitations which rationalists and Stalinists through the ages have tried to impose on it to make it easier for them to understand' (Apuleyo Mendoza and Garcia Márquez 1983.pp.59-60). One could argue that children's literature occupies a similar margin. where it has quietly been critiquing the rationalists and Stalinists (adults) for many generations, although that critique is paradoxically frequently mixed with the conservative goal of teaching children how to be good citizens, as has been noted by critics of children's literature such as Peter Hollindale. 
Jacqueline Rose, and Perry Nodelman.

of course, children's literature is not written by children. but by adults who endeavour to capture the child's or adolescent's view of the world when taking an antibureaucratic stance. thus calling into question the authenticity of that stance. Creating a magical realist text is. however, an act of imagining the world from other perspectives, of seeing it differently from the rationalist view of the past two hundred or more years. Writers for adult readers of magical realism have adopted the form much later than those writers for children, who have been using a mix of realism and fantasy for most of the twentieth century to suggest that the world is not exactly the way grown ups (rationalists) describe it.

Such a suggestion runs clearly throughout not only Black Maria but also Diana Wynne Jones's work as a whole. She has written that she is not able to believe in most people's version of normal life' (Jones 1989a, p.168). A main focus in most of her work is power-who has it. how it is used, and, most importantly, that children possess more power than they are aware of. She has said that she wants to 'show children how close to the old heroic ideal they so often are' (Jones 1989b. p.134), by which she means that 'children do, by nature, status, and instinct, live more in the heroic mode than the rest of humanity. They naturally have the right naive. straightforward approach. And in every playground there are actual giants to be overcome and the moral issues are usually clearer than they are. say, in politics' (1989b. p.133). Ideas and issues she addresses in her work are common to magical realism texis in general. For example. the manipulation of people as a way to achieve power. common in many magical realist texts, is apparent in her oeuvre, often perpetrated by adults over other adults and children as a means for gaining either economic power (the uncle in The Lives of Christopher Chant, 1988) or to fulfil emotional needs (Polly's mother in Fire and Hemlock, 1985). Another idea common in magical realism concerns the power of words; they create reality, even if that reality is in fact magic. Sophie's power in Howl's Moving Castle (1986) and Castles in the Air (1990) comes from her ability to talk objects into fulfilling her desires. Furthermore, Jones frequently connects the power of words to the idea that the magical exists in the commonplace or the domestic, another common element of magical realism. Sophie makes hats that transform or enhance their wearers while Tanaqui's weaving. in The Spellcoals (1979), is powerful, both in the recording and the creating of myths. Of course, not all of these examples from Jones's work are magical realism, but the fact that so many of her works demonstrate concerns and techniques similar to those found in adult magical realist texts suggest that her texts that do combine realism and magic fit the category of magical realism.

In connecting the domestic with power, Jones also touches on the larger issue of gender, a topic she tiptoes around in the majority of her fiction. John Stephens has written that when it comes to issues of gender, Jones is surprisingly conservative to the point of sexism (Stephens 1992, p.9), and to some extent, he is right. Jones does present strong women and girls but often the purpose of their strength is either to connect with or to save the men in their lives (Polly in Fire and Hemlock, or Ann/Vierran in Hexwood) This depiction of women and their relationships may be the most realistic element of Jones's work: much of society still operates within the terms reflected in her stories.

In Black Maria, the main conflict centres on the division of power between the sexes. With the isolated seaside resort of Cranbury-on-Sea as a microcosm of larger society, much as García Márquez used Macondo as a distillation of Colombian (and Latin American) society, Black Maria depicts the essential strengths of men and women as two different sorts of power that can be separated from people, made tangible. and then placed in a specific container or containers. So in Cranbury-onSea, men's power is captured in an intricately carved green box and women's power is invested in one woman and her twelve female supporters. The story recounts the events that transpire during a struggle for those powers, one side trying to consolidate the powers for their own use, the other trying to free them for everyone's use. When the narrator, Mig Laker, her brother, Chris, and her mother, Betty, spend Easter holidays with Mig's and Chris's father's aunt, Maria, in Cranbury-on-Sea, they become involved in the struggle. The Lakers contribute a great deal to undoing the rigid hierarchy and rules established by the manipulative, power hungry Maria. 
Although Black Maria was published in 1991, it was written some time before that. In 'Tennis Stars and Heroes', a speech by Jones printed in Magpies, she places Black Maria's writing right after The Time of the Ghost and just before Fire and Hemlock (Jones 1993, p.7), which means she wrote it some time between 1980 and 1984. Establishing this approximate date of BlackMaria's writing is important for two reasons. First, the thematic concerns and narrative techniques of Black Maria are similar to those found in Time of the Ghost and Fire and $H c m l o c k$, and the novel fits logically between them. The pattern of exploring gender continues with Howl's Moving Castle (1986) and Castles in the Air (1991), but with those two later novels, Jones employs a different form of fantasy than the one she uses in The Time of the Ghost, Fire and Hemlock, and Black Maria. In those novels. Jones carefully grounds the magical elements in realistic settings, while in the Howl and Sophie novels, she suggests multiple worlds, in the pattern of the Narnia books. The establishment of Black Maria's time of writing is important also because it was written at about the same time Midnight 's Children was published, 1980, and while I do not claim Rushdie's work had a direct influence on Jones, I do find it intriguing that one of the novels frequently mentioned as an exemplar of magical realism in fiction for adults appeared at roughly the same time Jones was experimenting with similar storytelling techniques.

Midnight's Children, Rushdie's five-hundred-plus-page novel, recounts India's history from 1915 to 1979. The narrator, Saleem Sinai. links the lives of his grandparents, parents, aunts and uncles, himself, and his son to the events of pre-and post-independence India. Because he is a first person narrator, Saleem's reliability is suspect. but it is cast further in doubt because he is convinced that he personally is responsible for many of the major historical and political events in India. Narrating the events of the preceding two generations and then of his childhood. adolescence, and young adulthood, Saleem connects his actions to the history of India in often convoluted and detailed ways. He tells us, 'Tounderstand just one life, you have to swallow the world' (p.126).

Black Maria does not try to feed us a world as Midnight's Children does. It looks at the abuse of power within a municipal and family community, Midnight's Children at the abuse of power in the national and international community. Both stories, however, fulfill the basic structural requirements for magical real ism: they combine realism and fantasy and do so in ways that create resolved antinomy: that is, the mix is presented as perhaps unusual but not horrifying. Jones is conscious of creating this combination, stating that she has worked to 'implant the far-off supernatural into the here-and-now' (1989b,p.133) and to create 'an exciting and exacting wisdom, in which contemporary life and potent myth are intricately involved and superimposed' ('Jones' 1993, p.118). Rushdie also consciously mixes the two; he sees it as 'a way of echoing in the form of our [Anglo Indian writers'] work the issues faced by all of us: how to build a new. "modern" world out of an old, legend-haunted civilization, an old culture which we have brought into the heart of a newer one' (Rushdie 1992, p.19).

Both stories have "an "enlightened" and rational view of reality' (Chanady 1985, p.21); that view is expressed through the essentially realistic settings. As Faris points out, 'Realistic descriptions create a fictional world that resembles the one we live in, in many instances by extensive use of detail' (Faris 1995, p.169). In most magical realist texts, the setting is recognizably of this world and remains so throughout. Such a setting is important, because the purpose of most magical realism is to encourage readers to rethink their perception of this world by presenting it as including rationalist, historicalfactual elements but also including more than rationalism usually acknowledges, or highlighting the irrationality of the realistic. Rushdie clearly sets Midnight's Children in various parts of India and Pakistan, with historic events and people named, dates given, and specific places described, because Rushdie is writing about the history of the place and its social, political, and cultural ramifications. In Black Maria, the historical references, dates, and places are not specifically detailed, for Jones's focus is different: she concentrates on personal relationships, putting them in a historical context towards the end of the story when she places the division of the genders in Cranbury-on-Sea as starting 'early in the Middle Ages' (Jones 1992, p. 178), but not emphasizing the context as Rushdie does in Midnight's Children. Nonetheless, Black 
Maria is obviously set in present day England. The realism is created through a number of references to London and the details of mundane daily life: groceries and shops, tea and fish and chips, trains and commuter parking lots, the dreariness of a seaside resort in the off season.

Another important factor in the creation of magical realism is, of course, the magic. In these two novels, there are clearly magical elements, although not as many as one might expect. For a novel of some five hundred pages that is discussed as a standard magical realist text, Midnight's Children has relatively few clearly magical events or characters. Most of the magical in the novel actually has to do with use of language. of wordplay and image. such as when Adam Aziz. the narrator's grandfather, is introduced. The opening sentence of the paragraph begins, 'On the moming when the valley, gloved in a prayer-mat. punched him on the nose' (p.5), but by the end of the paragraph it is quite clear that he stumbled and fell. Throughout the novel. Rushdie and his narrator Saleem use wording to push the audience to question its perception of reality as ordered and absolute.

Still, there are some elements that one could call actual magic, such as the central element of the story, the congress of midnight's children-that collection of one thousand and one children born in the first hour of August 15, 1947. who can communicate with each other through Saleem and who have a wild and varied collection of magical talents, ranging from the twin sisters in Baud who despite their impressive plainness ... both possessed the ability of making every man who saw them fall hopelessly and often suicidally in love with them' (p.235) to those who, Saleem says, 'were little more than freaks: bearded girls, a boy with the full-operative gills of a freshwater mahaseer trout' ( $p .238$ ). In addition to the children, there are a number of ghosts who converse with the living, as in other magical realist texts such as One Hundred Years of Solitude, and there is al so the marvel of the food that takes on and passes along the emotions of the cooks (p.164), as in Laura Esquivel's Like Water for Chocolate (1989).

Rushdie's ultimate purpose in blending the wordplay with actual magical events is to point out the degree to which much of history is not concrete reality but perception. Saleem says that India itself is a country which would never exist except by the efforts of a phenomenal collective will-except in a dream we all agreed to dream; it was a mass fantasy shared in varying degrees by Bengali and Punjabi, Madrasi and Jat ... India, the new myth-a collective fiction in which anything was possible' (pp.129-30). Thus, reality is often not nearly as concrete or set as we think it is-nation creating is a magical sort of process requiring collective will, much word play, and some outright fantasy.

With Black Maria, much the same point can be made, not about nation creating but about gender divisions. The magical elements of the story serve to reinforce the overall idea that separating male and female powers and duties is ultimately an arbitrary and constructed situation. existing because of collective will. Jones's use of magic in Black Maria is somewhat more straightforward than Rushdie's, connecting with the audience for whom the story is published: children's and young adult magical realist texts tend to be less worried about coping with audience disbelief and thus are more frank about magic. using less word play than found in texts for adults. Having said that, anyone who has read Jones's work knows that she is one of the more complex writers of children's and young adults' literature and word play is one of her strengths. At the start of the story, Mig and her brother, Chris, make jokes about the places and people they encounter. They call the men of the village 'zombies' whose wives have taken 'their souls away and then sen[t] them out ... to earn money' (Jones 1992, p.49), and they joke about Aunt Maria being a queen bee and all her women friends being workers (p.73). It turns out that their jokes state actualities. This process, a kind of literalization. fits with the second secondary characteristic Faris identifies, the 'verbal magic' in which metaphors become real. In this case, what at first seem to be analogies prove to be exact descriptions.

This movement from jokes to realizing their literal truth is part of a larger pattern in the story. It takes a while for the actual magic to begin; at first there are just odd impressions and coincidences: Aunt Maria's house is small from the outside but seems much bigger on the 
inside (p.15); by the end, when Aunt Maria has been vanquished, the house has disappeared completely from the street (p.204), suggesting it was a physical impossibility from the start. The grey fluffy cat looks very like Aunt Maria's missing companion Lavinia (p.68). and toward the end of the story it turns out that the cat is indeed the transformed Lavinia (p.205). Throughout the story, the pattern is to establish an effect or idea that seems quite commonplace and then reveal later its supernatural qualities.

There are, however, some very straightforward magical events in Black Maria. The metamorphoses Faris identifies as the fifth secondary characteristic of magical realism occur when Mig sees Chris and Aunt Maria's daughter transformed into wolves (pp.87-8: 159), and when Mig and her mother are transformed into cats. This transformation into cats make it easier to travel back and forth in time, another clearly magical element. In addition. Antony Green is buried alive (pp.156-57) and exhumed twenty years later, still alive (p.165-66), and Aunt Maria is finally shrunk to the size of bracelet charm (p.195).

These magical events are more concretely described than those in Midnight's Children, but the two stories do share some similar events. In Midnight's Children, Saleem, at the age of ten. begins to contact the other midnight children by projecting a picture of himself into each one's mind: 'It took me a little while to realize that my picture of myself was heavily distorted by my own self consciousness about my appearance; so that the portrait I sent ... was about as hideous as a portrait could be' (Rushdie 1980, p.262). In Black Maria, almost from the start, Chris sees a ghost in his room. Eventually, Mig, with help, figures out that the ghost is actually a projection, a sending, if you like, in which a living person sends some part of himself from one place to another' (Jones 1992, p.141). Mig describes the projection as 'oddlooking' (p.101). When Mig finally meets the projector, Antony Green, she realizes that his face is not the caricature he projected: 'The ghost was Antony Green's idea of himself. not what he really looked like' (p. 154). Both novels thus present such projection as possible and suggest the problems associated with it.

In both novels. the line between the real and the magical is problematic because both use first person narrators. Most magical realist texts use third person, creating an authoritative voice that reassures us about the veracity of the mixed natural and supernatural elements. In these two texts, however, we have to decide whether Mig and Saleem are telling us the truth. They both insist on the reality and actuality of their stories, and both speak of their 'autobiography', insisting that we are reading fact retold. Mig writes, 'Oh, heavens, how I wish this really was a story I was writing! I'd write in a happy ending this moment. But it isn't, it's real, and it goes on and on' (Jones 1992, p.95). Saleem says, 'To anyone whose personal cast of mind is too inflexible to accept these facts, I have this to say: that's how it was; there can be no retreat from the truth' (Rushdie 1980, p.236). Yet, they also are clear that the process of writing has its influence upon the nature of the story being told. The gaps that are part of living an experience become filled in when the experience is retold, and thus writing is not exactly reality, even if the events recorded are actual. As his story progresses, Saleem becomes very frank about the way his writing changes what happens: 'I, Saleem, intend briefly to endow myself-then with the benefits of hindsight: destroying the unities of and conventions of fine writing. I make him [his child seln] cognizant of what was to come. purely so that he can be permitted to think the following thoughts...' (p.283). Mig presents her story as something she wrote as the events were happening, thus establishing its reality, but at the end she admits. "That was all six months ago now. I have spent the time rewriting this autobiography ... Sometimes 1 have added bits and sometimes I have cheated a bit so that it looks as if I wrote more than I did ... I want it to be good when I finish it' (Jones 1992. pp. 206-7). Both want to tell a good story. In this desire, they are both magical realists, for there is a strong tendency to highlight, as Faris says. "the magical power of fiction itself (Faris 1995, p.175). Mig and Saleem demonstrate that writing is magical-it transforms experience.

Both narrators do work as Chanady suggests narrators in magical realist texts should: they may express surprise at the magical events but they never are condescending or dismissive of it. The magic exists and is a natural part of the world, if something not always encountered. As well 
both Mig and Saleem work to show that the rational and the supernatural coexist and are not separate from each other. that they can be part of a coherent whole. Both express this coherence by talking about magical elements using rationalist, scientific language. Mig conveys, we presume accurately, the discussion Mr. and Miss Phelps have about the ghost she and Chris have been seeing: 'Your ghost,' said Miss Phelps to me, 'is not a ghost in our opinion. It is a personal projection, a sending, if you like, in which a living person sends some part of himself from one place to another. The light will be caused by the force used by the sender changing the particles of air to form the image. Some images can speak.' (Jones 1992 , p.141). Although the science is suspect to those outside the text, the language, matter-of-fact manner, and adult speaker all contribute to normalize the paranormal. In Midnight's Children, Saleem says of his telepathic abilities that the laws of Doppler shift continued to operate in these paranormal realms, and the voices grew and diminished as the strangers passed' (Rushdie 1980 , pp.200-1), placing his mind-reading abilities within the rationalities and limitations of scientific phenomena. In both stories, the narrators and other characters help to make ordinary or natural the supernatural elements and thus create the resolved antinomy of which Chanady speaks.

Another characteristic of magical realism is what Faris calls its 'antibureaucratic' position (Faris 1995, p.179). In both Black Maria and Midnight's Children, one specific character embodies the bureaucracy or authority being criticized. At the heart of each story, there is a very powerful older woman who is the source of most conflict and horror for each narrator. For Mig, that powerful female figure is Aunt Maria Laker. the Queen Bee of Cranbury-on-Sea, who takes the power she has been given as leader of the women in the community and uses it to consolidate her own power through manipulation. imprisonment, transformation, and death of other members of the community, including her own daughter. For Saleem, many women affect his life, but the one who wields the most power is the Widow, his term for Indira Gandhi. Her political policies that began as an effort to better the lives of all people of India became, in Saleem's estimation, the effort to retain and build her own personal power. That bid for power results in the imprisonment, transformations, and deaths of many people.

The descriptions of both women have striking similarities. Both are presented as having two sides. Aunt Maria appears to be a sweet old lady, and Mig frequently describes her as fuzzy or like a teddy bear (Jones 1992. pp.36. 73, 195). At the climax of the story, when Aunt Maria is coercing Mig, the incongruity amazes and terrifies Mig: 'She had her most kindly teddy-bearish look. ... Here were all these peculiar and awful things going on. and you know all about them and wanted to scream and yell and cry, and yet here was Aunt Maria, so gentle and cuddly and civilised that you couldn't quite believe the awful things were happening.' (p.181). While Saleem never presents the Widow as cuddly, she does have a duality: 'Her hair parted in the centre, was snow-white on one side and blackasnight on the other' (Rushdie 1980. p.477). Saleem equates the duality with the economy of India, the 'white' official part and the 'black' underground and corrupt part, and with the two sides of the Emergency, the eighteen-month period from 1976 to 1977 when Indira Gandhi suspended the constitution of India. Saleem tells us that the Emergency had a white part-public, visible, documented, a matter for historians-and a black part which, being secret macabre untold. must be a matter for us' (p.501). In the case of both women, their dual nature heightens the horror of their power-hungry side, points up their hypocrisy, and communicates the idea that often evil is not immediately obvious as such.

The roles the two women play, however. differ in scope. In terms of the size of their constituency. Aunt Maria's is relatively small, affecting chiefly the small population of Cranbury. We are meant, however, to understand that her actions have parallels in the larger world. Exactly what Aunt Maria is after is not clear. Chiefly, she is the exemplar for all that the siory wants to communicate as bad. She lies at the centre of discussion about gender, a voice constantly reinforcing the 'rules' of gender behaviour, but she also acts in a dictatorial manner not usually associated with women. so that she becomes the embodiment of hypocrisy. She wants to be in control and have everyone subsuming themselves to her desires, as Mig's mother observes: 'She's utterly selfish and a 
complete expert at making other people do what she wants' (Jones 1992, p.37). She also wants to maintain the historical status quo in Cranbury, described as:

Men's ways with the power shut in the box. Women's ways with the virtuc hoarded in the Queens....

It goes back to the time when somebody here decided that men and women were different that the rules for the ways they used the power should be different.... Women allowed men the strong, out-of-doors things-provided the men put the virtue of their thoughts and ambitions into this box, ro that it couldn't get loose and run wildwhile men gave over all the secret, indoors things to the women-on condition the main power was kept safe by just a few strong women who would work by the rules. Those are the ones we call the Queens. (p.178)

Paradoxically, that division of powers and Aunt Maria's ambition for complete control inside and outside her home contradict each other, just as her many comments about suitable female behavior contradict the actual role she plays in Cranbury. Ultimately, she is a force against which Mig articulates her view of how she should act: 'I walked home feeling cross with myself. I pride myself on having ideas, but all the time we've been in Cranbury, I've been letting Chris do all the real active thinking. ... I think it is the way everyone here takes for granted that having ideas is not women's work and not nice somehow. In future, ! swear to do better.' (p.110).

The Widow's role is not quite as complicated as Aunt Maria's. She wants to be the centre of Indian identity, according to Saleem's assessment, presented as questions: -Was my lifelong belief in the equation between the State and myself transmuted, in "the Madam' $s$ " mind. into that in-those-days-famous phrase: India is Indira and Indira is India? Were we competitors for centrality-was she gripped by a lust for meaning as profound as my own ... ?' (Rushdie 1980, p.501). Unlike Maria's narrow realm of influence, the Widow's affects thousands if nor millions of people throughout India, although Saleem concentrates on her effect upon the four hundred and twenty remaining midnight's children.
In terms of space the two women occupy in their respective texts. Aunt Maria actually dominates more thoroughly than does the Widow. She is the focal point for all the developments and actions in the story, a role Indira Gandhi cannot occupy, for India itself plays that role in Midnight's Children. This difference is consistent with children's literature's concentration on the personal rather than the public: Black Maria concentrates on the family dynamics as a trope for the larger society, whereas Midnight's Children focuses on the larger society, acknowledging its similarities to family while simultaneously portraying the real distunce between political figures and the people they govern: we are never actually in the presence of Indira Gandhi at any point in the novel. Nonetheless, her actions have a profound effect and Saleem is convinced that she is particularly after him: "Mother Indira really had it in for me (p.502). Mig realizes that Aunt Maria has it in for her, though in a way different from the Widow's: 'I still didn't understand that Aunt Maria meant me to be her successor, not until ages more droning on' (Jones 1992, p.182).

In both stories, these women who manipulate and control others are both abusers of magic and power that should be put to better and higher use. Maria's powers reside in her speech, her use of words, a power Mig has as well. Mig. however, uses her power to tell a story, to communicate a message about not abusing power, while Maria abuses her power ro gain more power for herself. The Widow does not have magical powers per se, except perhaps omniscience. but she fears and abuses the powers of midnight's children, and uses the children against each other. Saleem's ideal of the children leading India to a new kind of unity (Rushdie 1980, pp.306.7) is crushed by the '-ectomies' (p.523) performed upon them at the Widow's command, and thus India is doomed to tear itself apart. The optimism credited to children's literature is apparent in the fate of Maria-she is shrunk to the size of a small charm and set adrift on the sea, leaving Cranbury to sort itself out. In Saleem's story, the Widow's fate is less satisfaciory, consisting only of the embarrassment of a lost election (p.525), and so the story ends on a note that seems less optimistic about the ability to overcome power hungry dominatrices than is Black Maria.

There are more connections possible between these two texts, but their presentation of realism and magic, their 
use of narration, and their portrayal of female antagonists are major similarities between them. Those similarities help to demonstrate that although the two differ in their specific focus and in the scope of theme and content, they share techniques and effects and fulfill many of the elements common to most magical realist texts.

Their differing scopes undoubtedly connect with audiencechildren's stories generally do focus more on the personal rather than on the largerpublic arena. The matter of differences between children's and adults' literature is tricky, often difficult to pin down. When Margery Fisher, in The Bright Face of Danger, examines children's and adult's forms of the same genre, the adventure story, she sees 'differences between adventure stories for adults and for children, but ... those differences-of tone. of approach, of subject matterare less important than the way stories are read by adults and children ... the adventure story should be read with the openly imaginative, susceptible, unprejudiced response which belongs to youth but which can be summoned up in later years' (p.10). The comment that the way the stories are read is important echoes one of Faris's secondary characteristics of magical realism: 'The narrative appears to the late-twentieth-century adult readers to which it is addressed as fresh, childlike, even primitive. Wonders are recounted largely without comment, in a matter-of-fact way, accepred-presumably -as a child would accept them' (p.177). Not only, says Faris, does the magic realist text for adults present its material in a childlike form but it elicits a childlike response. Of course, for those of us who deal with the difficulty of defining childlike. Faris's comment is problematic. By childlike, she implies unsophisticated, without a sense of differentiation between fantasy and reality, an implication of Fisher's comments also. I suggest that both adult and child audiences make a choice to accept the mix. It may be that adult audiences are more conscious of doing so, largely because they have been discouraged since they were teenagers from thinking of fantasy as acceptable adult reading. This question of audience reception and what engenders it is a discussion that deserves another entire article: the point that we can take from Fisher and Faris's comments is that when we discuss magical realism. the attitude the readers bring to the texts is important, a point that is true regardless of the intended audience or the age of the reader.
Fisher's other observation in that quotation, that adventure stories for children and for adults do have differences in tone, approach, and subject matter is apparent in magical realism for the two audiences, and those three elements add up to the difference in scope: most magical realist texts for adults border on the epic, covering major specific events in history such as Midnight's Children does or depicting shifts in power and thought that have affinity to specific historical eras or places, as in One Hundred Years of Solitude. Those for children tend to be more focused in terms of historical moment and also tend to concentrate on the main character's progress more optimistically than those for adults. For example, at the end of Midnight's Children. Saleem is about to shatter into six hundred million particles, while at the end of Black Maria, Mig and her family have safely escaped Aunt Maria, rescued the people of Cranbury-on-the-Sea. and retumed home to rebuild their family.

Neither ending is, however, as simple as first appears. Rushdie has said that he sees the end of Midnight's Children as essentially optimistic. Differentiating between the narrator and the author, he says 'The form-multitudinous, hinting at the infinite possibilities of the country-is the optimistic counterweight to Saleem's personal tragedy. I do not think that a book written in such a manner can really be called a despairing work' (Rushdie 1992, p.16). At the end of Black Maria, everyone survives, but the divorce of Mig's parents, the problem established at the start of the story, goes ahead. and the rebuilt family is not stable in the traditional sense. Both Antony Green. Mig's mother's new love and Chns, Mig's brother, are deeply affected by their experiences at the hands of Aunt Maria (Antony buried alive and Chris turned into a wolf) and neither can bear to be too confined, which. of course, affects the family dynamics (Jones 1992, p.206). As Nodelman comments abour children's texts in general. their apparent simplicity contains depths. often surprisingly pessimistic qualifications of the apparent optimism. dangerously and delightfully counterproductive possibilities that oppose and undermine the apparent messages' (Nodelman 2000. pp.1-2). Such qualifications of optimism are obvious in Jones's work, which is given to ambiguous endings that temper the happiness of resolved conflicts by suggesting that resolution is never complete. The possibility of perceiving that ending as happy, however, marks children's literature as different from much of that for adults. 
The commonalities between Black Maria and Midnigh's Children suggest that children's and young adults' texts have as much right to be considered magical realism as those for adults, and that there really is no need to create dozens of categories to describe stories in which realism and fantasy combine to create a coherent whole. That children's literature has not yet been included in discussions of magical realism. or magical realism criticism included in discussions of children's literature, suggests that assumptions about audience outweigh the formal qualities of such texts. More thinking needs to be done about how magical realism in children's literature operates, for the form has existed in children's literature for most of the twentieth century. Works such as Nesbit's Five Children and $/ \mathrm{t}$ or The Enchanted Castle may well provide insights to the study of adult magical realism, just as studies of magical realism may provide interesting views of Nesbit's work, as well as that of many other writers of children's fantasy.

\section{NOTES}

1. The one discussion I found that does classify some children's and young adult's fantasy fiction as magical realism. Cathi Dunn McRae's Presenting Young Adult Fantasy Fiction (1998), seems based on little or no research into the term, for it includes in that classification books such as Alice's Adventures in Wonderland, Andre Norton's Witch World series: Stephen R. Donaldson's Chronicles of Thomas Covenant the Unbeliever, and Antoine Saint-Exupéry's The Litlle Prince. These stories use techniques of storytelling and employ fantasy elements that are quite different from each other and from generally accepted definitions of magical realism.

2. Working from definitions provided by Robert Scholes and Ulrich Wicks, Amaryll Chanady defines mode as a 'particular quality of fictitious world that can characterize works belonging to several genres, periods or national literatures' (Chanady 1985, p.2).

3. Magical Realism: Theory. History, Community, edited by Lois Parkinson Zamora and Wendy B. Faris, offers the best introduction to the history of the definition of magical realism. Its first section. 'Foundations', includes many of the seminal articles discussing the term. Another useful article that gives a quick overview of the term's definitions is William Spindler's 'Magical Realism: A Typology'.

\section{REFERENCES}

Apuleyo Mendoza, Plinio and Gabriel García Márquez (1983) The Fragrance of Guava. London, Verso.

Chanady, Amaryll Beatrice (1985) Magical Realism and the Fantastic: Resolved versus Unresolved Antinomy. New York, Garland.

Chanady, Amaryll Beatrice (1995) 'Territorialization of the Imaginary in Latin A merica'. in Zamora and Faris, Magical Realism: Theory, History, Community, pp.125-144

Egoff, Sheila (1988) Worlds Within: Children's Fantasy from the Middle Ages to Today. Chicago, ALA.

Faris, Wendy B. (1995) 'Scheherazade's children: Magical realism and postmodern fiction', in Zamora and Faris, Magical Realism: Theory, History, Community. pp.163-190.

Fisher, Margery (1986) The Bright Face of Danger. London. Hodder and Stoughton.

Gannon, Susan R. (1987) 'One more time: Approaches to repetition in children's literature'. Children's Literature Association Quarterly 12.1: 2-5.

Jones. Diana Wynne (1989a) 'Diana Wynne Jones 1934-' Something About the Author Autobiography Series. Detroit. Gale. pp.155-170.

Jones, Diana Wynne (1989b) 'The heroic ideal-a personal odyssey'. The Lion and the Unicorn 13,1: 129-140.

Jones, Diana Wynne (1991) Black Maria. London, Mammoth. (Published in USA as Aunt Maria).

Jones, Diana Wynne (1993) 'Tennis stars and heroes'. Magpies 8, 5: 5-11.

'Jones, Diana Wynne 1934-' (1993) Something About the Author 70. Detroit, Gale. pp.115-118.

Lynn. Ruth Nadelman (1995) Fantasy Literature for Children and Young Adults: An Annotated Bibliography. New York. Bowker.

MacRae, Cathi Dunn (1998) Presenting Young Adult Fantasy Fiction. New York, Twayne.

Nikolajeva, Maria (1994) 'Stages of development: Folklore elements in children's literature', Canadian Children's Literature 73: 48-54.

Nodelman. Perry (2000) 'Pleasure and genre: Speculations 
on the characteristics of children's fiction'. Children's Literature 28: 1-14.

Rushdie, Salman (1991) Midnight's Children. New York. Penguin.

Rushdie, Salman (1992) 'Imaginary homelands', in Imaginary Homelands: Essays and Criticism 19811991. London, Granta/Penguin, pp.9-21.

Saltman. Judith (1985) The Riverside Anthology of Children's Literature. $6^{\text {th }}$ ed. Boston. Houghton Mifflin.

Slemon, Stephen (1995) 'Magical realism as postcolonial discourse'. in Zamora and Faris, Magical Realism: Theory, History, Community, pp.407-26.

Spindler. William (1993) 'Magical realism: A typology'. Forum for Modern Language Studies 29,1: 76-85.

Stephens, John (1992) Language and Jdeology in Children's Fiction. London and New York, Longman.

Sullivan, C. W. III (1990) 'Narrative expectations: the folklore connection', Children's Literature Associaton Quarterly 15,1: 52-55.

Waggoner, Diana (1978) The Hills of Faraway: A Guide to Fantasy. New York, Atheneum.

Walsh. Jill Paton (1977) 'The rainbow surface', in The Cool Web: The Pattern of Children's Reading London. The Bodley Head, pp.192-93

Zamora, Lois Parkinson and Wendy B. Faris. (eds.) (1995) Magical Realism: Theory. History, Community. Durham. Duke UP.

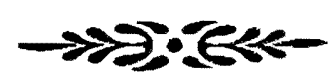

\section{BIOGRAPHICAL NOTE}

Teya Rosenberg has a Ph.D in children's literature from the University of Alberta, Canada. An assistant professor in the English department at Southwest Texas State University. she teaches courses in children's literature, mythology, magical realism, and Canadian fiction. A former associate editor of Children's Literature Association Quarterly, she is currently editing a collection of essays on the works of Diana Wynne Jones. 